\title{
Molecular Mechanism and Health Role of Functional Ingredients in Blueberry for Chronic Disease in Human Beings
}

\author{
Luyao Ma ${ }^{1,2}$, Zhenghai Sun ${ }^{1,2, *}$, Yawen Zeng ${ }^{3, *(1)}$, Mingcan Luo ${ }^{2}$ and Jiazhen Yang ${ }^{3}(\mathbb{C}$ \\ 1 Economics and Management College, Southwest Forestry University, Kunming 650224, China; \\ ma403294928@163.com \\ 2 Key Laboratory for Forest Resources Conservation and Utilisation in the Southwest Mountains of China, \\ Southwest Forestry University, Ministry of Education, Kunming 650224, China; lmc1961@sohu.com \\ 3 Biotechnology and Germplasm Resources Institute, Yunnan Academy of Agricultural Sciences, \\ Kunming 650205, China; yangjiazhen415@163.com \\ * Correspondence: sunzhenghai1978@163.com (Z.S.); zengyw1967@126.com (Y.Z.); \\ Tel.: +86-138-886-98405 (Z.S.); +86-130-853-95543 (Y.Z.)
}

Received: 24 August 2018; Accepted: 12 September 2018; Published: 16 September 2018

\begin{abstract}
Functional ingredients in blueberry have the best health benefits. To obtain a better understanding of the health role of blueberry in chronic disease, we conducted systematic preventive strategies for functional ingredients in blueberry, based on comprehensive databases, especially PubMed, ISI Web of Science, and CNKI for the period 2008-2018. Blueberry is rich in flavonoids (mainly anthocyanidins), polyphenols (procyanidin), phenolic acids, pyruvic acid, chlorogenic acid, and others, which have anticancer, anti-obesity, prevent degenerative diseases, anti-inflammation, protective properties for vision and liver, prevent heart diseases, antidiabetes, improve brain function, protective lung properties, strong bones, enhance immunity, prevent cardiovascular diseases, and improve cognitive decline. The anthocyanins and polyphenols in blueberry are major functional ingredients for preventive chronic disease. These results support findings that blueberry may be one of the best functional fruits, and further reveals the mechanisms of anthocyanins and polyphenols in the health role of blueberry for chronic disease. This paper may be used as scientific evidence for developing functional foods, nutraceuticals, and novel drugs of blueberry for preventive chronic diseases.
\end{abstract}

Keywords: blueberry; functional ingredients; chronic disease; functional food

\section{Introduction}

Berries are the best dietary sources of health benefits, these benefits are associated with their specific chemical and biological properties, such as Rosaceae Rubus (raspberry and blackberry), Fragaria (strawberry), and Ericaceae Vaccinium (blueberry and cranberry), major bioactive compounds contain anthocyanins, phenolic acids, ascorbic acid, flavonols, and tannins [1]. Berry anthocyanidins (cyanidin, malvidin, peonidin, petunidin, and delphinidin) have various anticancer effects [2] however, cyanidin and peonidin have similar anticancer effects to that of black rice [3]. Berry meals should be used as an important source of phenolics for human health, especially the decreasing order of the total phenolics, scavenging, and chelating capacity for blackberry $>$ black raspberry $>$ blueberry [4]. Berries (strawberry, raspberry, blackberry, and blueberry) have high total phenolic compounds, but significant differences in antioxidant capacity, i.e., blackberries and strawberries had higher anthocyanin content, meanwhile, the availability of total phenolic compounds was higher than anthocyanins (33-73\%) [5]. The concentrations of bioflavonoids in commercial berry 
juices (blackcurrant blueberry, red raspberry, and cherry) (mg/100 $\mathrm{g}$ of juice) are as follows. Luteolin-7-O-glucoside (5.6-10.2) > rutin (0.4-6.5) > quercetin $(0.21-5.12)>$ kaempferol $(0.05-1.2)$ $>$ kaempferol-3-O-glucoside (0.02-0.12), however blackcurrant $>$ blueberry $>$ red raspberry $>$ cherry for total flavonoids; the antioxidant activity of juice extracts is expressed as IC50 values from 8.56 to $14.05 \mathrm{mg} / \mathrm{kg}$ [6]. The total anthocyanin and polyphenol content in blueberry juice was higher, which also has higher antioxidant activity, but cranberry juice had a greater capacity than blueberry juice as an $\alpha$-glucosidase inhibitor [7].

Blueberry is one of the most nutritious foods and cultivated worldwide. The global total output of blueberry was 629,720 tons in 2016; major distributors of the blueberry in the world are USA, Chile, Canada, Spain, China, Morocco, and 30 other countries. The production of natural food pigments continues to grow worldwide with an annual growth rate of $6.22 \%$ from 2015 to 2019, especially five pigments (anthocyanins, carotenoids, betalains, and chlorophylls) which have been used to color foods [8]. Blueberry with abundant anthocyanins can improve vision, is anticancer, antidiabetes, anti-obesity, is preventive against neurodegeneration and macular degeneration as well as osteoporosis, can reduce hyperlipidemia and hypertension, as well as heart disease through its apoptosis, antioxidant, anti-inflammation, and anti-angiogenesis effects [9]. Blueberries with 15,886 expressed sequence tag-SSR (EST-SSR) loci were identified and 7705 simple sequence repeats (SSRs) of adequate flanking sequence were found [10]. Distinct anticarcinogenic effects associated with the different phytochemical signatures of blueberry (downregulating CYP1A1 expression), and black raspberry (downregulated ER $\alpha$ expression) [11]. Blueberry and mulberry juice can have anti-obesity properties based on being able to reduce insulin resistance and lipid accumulation and lower serum cholesterol and leptin secretin [12]. Blueberry juice and bifidobacteria improve nonalcoholic fatty liver disease by activating SIRTI-mediating signaling pathway [13].

\section{Functional Ingredients in Blueberry}

The bioactive components in blueberry include anthocyanins, polyphenols, and antioxidant properties. Pectin from blueberry powder included cyanidin-3-glucoside $\left(\mathrm{C}_{21} \mathrm{H}_{21} \mathrm{O}_{11} \mathrm{Cl}\right)$ and anthocyanidins, however anthocyanidins including cyanidin (color change with $\mathrm{pH}$, red $<3$, violet $7-8$, blue $>11$ ), pelargonidin $\left(\mathrm{C}_{15} \mathrm{H}_{11} \mathrm{O}_{5}{ }^{+}\right.$, orange), malvidin (blue), petunidin (dark-red, purple), and delphinidin (blue, blue-red), which may represent two major mechanisms of anthocyanin stacking and ionic interaction for pectin and anthocyanin binding [14]. Blueberries are extraordinarily rich in polyphenols, including 3-glucoside/arabinoside/galactoside-based polymers of delphinidins $\left(\mathrm{C}_{15} \mathrm{H}_{11} \mathrm{O}_{7}^{+}\right)$, petunidins $\left[\mathrm{C}_{16} \mathrm{H}_{13} \mathrm{O}_{7}{ }^{+}\left(\mathrm{Cl}^{-}\right)\right]$, peonidins $\left(\mathrm{C}_{16} \mathrm{H}_{13} \mathrm{O}_{6}{ }^{+}\right)$, malvidins $\left(\mathrm{C}_{17} \mathrm{H}_{15} \mathrm{O}_{7}\right)$, and cyanidins $\left(\mathrm{C}_{15} \mathrm{H}_{11} \mathrm{O}_{6}{ }^{+}\right)$[15]. The antioxidant properties of blueberry juices, total phenolic content $(0.85-2.81 \mathrm{mg} / \mathrm{g})$, quinic $\left(\mathrm{C}_{7} \mathrm{H}_{12} \mathrm{O}_{6} ; 0.203-3.614 \mathrm{mg} / \mathrm{g}\right)$ and chlorogenic acids $\left(\mathrm{C}_{16} \mathrm{H}_{18} \mathrm{O}_{9} ; 0.02-0.347 \mathrm{mg} / \mathrm{g}\right)$, and rutin $\left(\mathrm{C}_{27} \mathrm{H}_{30} \mathrm{O}_{16} ; 0.00-26.88 \mu \mathrm{g} / \mathrm{g}\right)$ have lager variation, however ABTS(+) scavenging capacity $(6.38-20.9 \mu \mathrm{mol} / \mathrm{g})$, ferric reducing antioxidant power (3.07-17.8 $\mu \mathrm{mol} / \mathrm{g})$, and oxygen radical absorbance capacity $(4.21-45.68 \mu \mathrm{mol} / \mathrm{g})$ [16] have less variation. Oral anthocyanins that go through the blood-brain barrier can improve visual function by increasing rhodopsin regeneration [9]. The detection limits $(\mu \mathrm{g} / \mathrm{L})$ of succinic $\left(\mathrm{C}_{4} \mathrm{H}_{6} \mathrm{O}_{4}, 2.5\right)$, citric $\left(\mathrm{C}_{6} \mathrm{H}_{8} \mathrm{O}_{7}, 2.0\right)$, salicylic $\left(\mathrm{C}_{7} \mathrm{H}_{6} \mathrm{O}_{3}, 3.4\right)$, malic $\left(\mathrm{C}_{4} \mathrm{H}_{6} \mathrm{O}_{5}, 1.5\right)$, benzoic $\left(\mathrm{C}_{6} \mathrm{H}_{5} \mathrm{COOH}, 2.2\right)$, sorbic $\left(\mathrm{C}_{6} \mathrm{H}_{8} \mathrm{O}_{2}, 0.8\right)$, ascorbic $\left(\mathrm{C}_{6} \mathrm{H}_{8} \mathrm{O}_{6}, 1.5\right)$, and tartaric acid $\left(\mathrm{C}_{4} \mathrm{H}_{6} \mathrm{O}_{6}, 4.5\right)$ in blueberry juices have been developed [17]. Colonic fermentation of wild blueberry polyphenols are degraded to syringic $\left(\mathrm{C}_{9} \mathrm{H}_{10} \mathrm{O}_{5}\right)$, cinnamic $\left(\mathrm{C}_{9} \mathrm{H}_{8} \mathrm{O}_{2}\right)$, caffeic $\left(\mathrm{C}_{9} \mathrm{H}_{8} \mathrm{O}_{4}\right)$, and protocatechuic acids $\left(\mathrm{C}_{7} \mathrm{H}_{6} \mathrm{O}_{4}\right)$ [18]. Blueberry (Vaccinium uliginosum L.) from the Chinese Changbai Mountains contained five main components (delphinidin $40.70 \%$, cyanidin $3.40 \%$, petunidin $17.70 \%$, peonidin $2.90 \%$, and malvidin $35.50 \%$ ), which could be a promising functional food to suppress colorectal cancers [19]. A Brazilian blueberry had very high content of total phenolics $(16.22-34.57 \mathrm{~g} / \mathrm{kg})$, total anthocyanins $(1.4-3.18 \mathrm{~g} / \mathrm{kg})$, and carotenoids [20]. Malvidin derivatives of blueberry had lower antioxidant capacity than that of blackberry; blackberry had the highest total antioxidant capacity which is associated with 
cyanidin-3-O-glucoside, which accounted for $94 \%$ of blackberry anthocyanins [21]. The juice obtained from Pulsed Electric Field pretreated blueberry had a significantly higher antioxidant activity $(+31 \%)$, total phenolic $(+43 \%)$, and anthocyanin content $(+60 \%)[22]$.

\section{Preventive Chronic Disease of Blueberry}

\subsection{Anticancer and Functional Ingredients of Blueberry}

Blueberry is a good source of anthocyanins and phenolic acids (see Table 1), which showed, not only higher tumor stayer and lower proliferative, antiapoptotic, and angiogenic transcript levels [15], but also prevented carcinogenesis and reduced the risks of cancer recurrence [23] as well as having potential as a radiosensitizer for treating cervical cancer [24]. Blueberry anthocyanins and their production with pyruvic acid $\left(\mathrm{C}_{3} \mathrm{H}_{4} \mathrm{O}_{3}\right)$ can slow the progress of cancer by inhibiting the proliferation of cancer cells [25]. Blueberry anthocyanin ranged from 1.02 to $1.95 \mathrm{~g} / \mathrm{kg}$ of malvidin-3-glucoside for fresh weight, which has antiproliferative and apoptotic properties in cancer cells and are used as chemopreventive metastasis [26], however its anticancer ability using HepG-2 cells is associated with the concentration of anthocyanins [27]. Mitochondria benefits from the protective effects of blueberry anthocyanin extract against acrylamide toxicity [28]. Pterostilbene in blueberries can control worsened/obdurate myeloma therapy and major therapeutic myeloma of bortezomib chemotherapy [29]. Lowbush blueberry proanthocyanidins can enhance apoptosis induction in human colorectal cancer cell lines, which represents important nutritional chemoprevention of colorectal cancer [30]. The dietary food for blueberry husks with probiotics can delay colonic cancer [31]. Blueberry juice has similar anti-premutagenic activity to vitamin $C$, and also acts a methylation suppressor for methylenete trahydrofolate reductase and DNA methyltransferase 1 in human [32]. Anthocyanin and anthocyanidin extracts from blueberry can inhibit the proliferation and trigger the apoptosis of B16-F10 cells [33]. Blueberry consumption (400 mg daily) can reduce tumor size significantly in mice, which inhibited the proliferation of ovarian cancer cells by downregulating the levels of cyclooxygenase-1 and cyclooxygenase-2 [34].

Table 1. Functional ingredients for preventive chronic disease in blueberry.

\begin{tabular}{ccc}
\hline Chronic Disease & Functional Components & References \\
\hline Anticancer & Anthocyanins, phenolic acids, pyruvic acid, & {$[15,25-30,33,34]$} \\
Anti-obesity & pterostilbene & {$[35,36]$} \\
Prevent degenerative diseases & Anthocyanins, polyphenols & {$[37-41]$} \\
Anti-inflammation & Anthocyanins, chlorogenic acid, polyphenols & {$[42-45]$} \\
Protective vision & Anthocyanins, phenolic acids, flavonoids & {$[46-48]$} \\
Protective liver & Anthocyanins, polyphenols & {$[28,49-51]$} \\
Prevent heart diseases & Anthocyanins, polyphenols & {$[52-54]$} \\
Antidiabetes & Anthocyanins, procyanidin, polyphenols & {$[35,55-57]$} \\
Improve brain & Anthocyanins, polyphenols & {$[58-62]$} \\
Protective lung & Anthocyanins, phenolics & {$[2]$} \\
Strong bones & Anthocyanins & {$[63]$} \\
Enhance immunity & Anthocyanins & {$[64,65]$} \\
Prevent cardiovascular diseases & Polysaccharide, polyphenols & {$[66-68]$} \\
Improve cognitive decline & Phenolic acids, flavonoid & {$[69]$} \\
\hline
\end{tabular}

\subsection{Anti-Obesity and Functional Ingredients of Blueberry}

Obesity is associated with the infiltration of monocytes into adipose tissue causing inflammation that is associated with metabolic abnormalities. Anthocyanins from blueberry dealcohol fermented beverages can inhibit insulin signaling in adipocytes, which induced insulin glucose uptake and reduced glycerol release in adipocytes [35] (see Table 1). Blueberry polyphenols can play an important role in inhibiting adipogenesis and cell proliferation [36] (see Table 1). Intake of blueberry leaf extract reduced body weight $(20 \%)$ and improved insulin resistance as well as prevent obesity in mice with a 
high-fat diet [70], however blueberry extract possess a therapeutic tool against comorbidities related with obesity [71]. Expression of fatty acid synthase was significantly decreased in the adipose tissue of the liver and abdomen when wild blueberry consumption was increased [72]. Obesity and diabetes are becoming a global health problem; however, freeze-dried blueberry powder can treat and prevent obesity-related chronic diseases [73].

\subsection{Prevent Degenerative Diseases and Functional Ingredients of Blueberry}

The blueberry has excellent antioxidant activity and $\alpha$-glucosidase inhibition [74]. The antiproliferative and antioxidants from blueberry juices are associated with anthocyanins; blueberry can prevent many degenerative diseases with daily consumption [37] (see Table 1). Anthocyanins can reduce the reactive oxygen species (ROS) and xanthine oxidase-1 (XO-1) capacities, but strengthen superoxide dismutase (SOD) and heme oxygenase-1 (HO-1), as well as malvidin capacities [38]. Four cultivars (Elliott, Rubel, Rancocas, and Friendship) with high anthocyanins and polyphenol content of 45 blueberries in Suwon have high antioxidant activity [39]. Chlorogenic acid concentration in lowbush blueberries is $0.44 \mathrm{mg} / \mathrm{g}$, the phenolic acid mixture exerts it anti-inflammatory properties by controlling nuclear factor- $\kappa \mathrm{B}$ activation and producing inflammatory cytokines at high dose [40]. Blueberry (fruit, pomaceas, and leaves) is one of the best sources of polyphenols with antioxidants, however its antioxidant activity is higher than that of rutin, especially, polyphenols in rabbiteye blueberry leaves has the highest antioxidant activity [41].

\subsection{Anti-Inflammatory and Functional Ingredients of Blueberry}

Dietary anthocyanins ameliorate inflammation and obesity as well as obesity-associated chronic diseases [75]. Phenolic acids (6.6\%), flavonoids (12.9\%), and procyanidins $(2.7 \%)$ in blueberry extract have antibacterial and anti-inflammatory activity [42] (see Table 1). Blueberry with plentiful anthocyanins can increases anti-inflammatory cytokines and reduces oxidative stress in acute ingestion [43] (see Table 1). Blueberry is used as a functional food for preventive chronic inflammation; however, the anti-inflammatory effect of malvidin-3-glucoside is better than that of malvidin-3-galactoside [44]. Wild blueberry consumption has an overall anti-inflammatory effect in the metabolic syndrome [76]. The antibacterial and anti-inflammatory effects protect the oral keratinocyte barrier as well as neutralize leukotoxin properties of blueberry proanthocyanidins which could be promising candidates as novel therapeutic agents [45].

\subsection{Protective Vision and Functional Ingredients of Blueberry}

Total polyphenol and anthocyanin contents with improving mammal vision in wild Chinese blueberries were 0.60 and $0.18 \%, 13$ anthocyanins were identified, especially malvidin (blue color) glycosylated with hexose $\left(\mathrm{C}_{6} \mathrm{H}_{12} \mathrm{O}_{6}\right)$ or pentose that accounted for more than $46 \%$ [77]. The consumption of anthocyanin blueberry hastened the recovery of visual acuity after photobleaching [46] (see Table 1). Anthocyanins in berries contribute to eye health, especially cyanidin-3-glucoside in blueberry, is a preventive functional food for the prevention of retinal diseases [47]. Blueberry polyphenols have the retinal protective activity against light-induced retinal injury in eyes [48] (see Table 1).

\subsection{Protective Liver and Functional Ingredients of Blueberry}

Hepatitis $C$ virus belongs to the genus Hepacivirus, which infects about 170 million people in the world and causes high rates of chronic hepatitis $(>75 \%)$, however oligomeric proanthocyanidin in blueberry leaves can inhibit RNA expression of the hepatitis C virus [78]. Diets containing blueberries markedly reversed the acrylamide-induced alterations in liver exerting strong antioxidant activities, significantly alleviating the DNA damage in liver cells [79]. Pretreatment of blueberry anthocyanin can inhibit reactive oxygen species formation, prevent mitochondrial damage and even dysfunction in mice liver [28]. The anthocyanidins and anthocyanins in blueberry can inhibit the four enzymes 
catalytic activities of human hepatocytes and microsomes, but cyanidin-3-O-rhamnoside and two glycosides of delphinidin markedly inhibited CYP450 [49] (see Table 1). Redox response against a toxic selenite of rat brain and liver dose was associated with blueberry polyphenols, especially chlorogenic acid and flavonols that take on significant antioxidant protective effects [50] (see Table 1). Blueberry extract can be used as a therapeutic agent in combating $\mathrm{Cd}(\mathrm{II})$-induced tissue injury of mouse liver, and its protective effect including antioxidative and anti-inflammatory properties with metal-chelating capacity [80]. The hepatoprotective effect of blueberry and chitosan significantly decreased liver arginase activity and ornithine levels, as well as increased nitric oxide and glutathione levels [81]. Regulating histone acetylation for anthocyanins from blueberries could improve liver function and liver fibrosis indexes in rats with hepatic fibrosis, which genes promote apoptosis and inhibit the effect of antihepatic fibrosis [51].

\subsection{Heart Disease Prevention and Functional Ingredients of Blueberry}

Blueberry anthocyanins eased cyclophosphamide-induced cardiac injury and improved oxidative stress and cardiomyocyte apoptosis [52] (see Table 1). Blueberry pomace with abundant procyanidins possesses protective effects against diabetes, obesity, and coronary heart disease; however, extrusion processing can increase monomer and dimers of procyanidin [53]. Blueberry polyphenols prevent adult cardiomyocyte hypertrophy and cell death associated with norepinephrine [54] (see Table 1).

\subsection{Antidiabetic Properties and Functional Ingredients of Blueberry}

Wild blueberry consumption is associated with glucose metabolism in metabolic syndrome obese rats [82]. The metabolism of blueberry anthocyanins lightens the endothelial dysfunction of lipid toxicity and lessens vascular complications associated with diabetes [55] (see Table 1). Blueberry can lighten vascular complications in diabetes as some of its metabolites can restore cell surface glycosaminoglycans and attenuate endothelial inflammation [83]. Oxidative stress plays a key role in diabetes and its complications; however, a blueberry dietary regime can treat type 1 diabetics [84]. Anthocyanin-rich wild Chinese blueberry can protect $\beta$-cells against glucolipotoxicity and prevent diabetes [56]. Blueberries prevent glucose intolerance and hepatic steatosis which are associated with gene expression of hepatic fatty acid oxidation [85]. Adipose inflammation promotes insulin resistance and other complications, however, dietary blueberry can combat obesity-associated pathology [86]. The anthocyanin-rich blueberry can temper the postprandial glucose response, and its implications for cognitive and type 2 diabetes research [57]. Blueberry supplementation improves component changes in the gut microbiota, related with improving general inflammation and insulin signaling in high-fat-diet rats [87].

\subsection{Improving Brain Health and Functional Ingredients of Blueberry}

Whole fresh blueberry reduced apoptosis and eased histopathological findings of D-galactose-treated rat brain [88]. The L-galactose pathway was major route of ascorbic acid biosynthesis and its higher expression levels are associated with five genes [guanosine diphosphate-mannose- $3^{\prime}, 5^{\prime}$-epimerase (GME), guanosine diphosphate-L-galactose phosphorylase (GGP), L-galactono-1,4-lactone dehydrogenase (GLDH), monodehydroascorbate reductase (MDHAR), and dehydroascorbate reductase (DHAR)] in blueberry fruits [89]. Blueberry anthocyanin diets of animals can prevent irradiation by reducing oxidative stress and inflammation, improving neuronal signaling and protective neuronal functioning with exposure high energy particles [90]. Anthocyanins in blueberry improve cognitive function promoting brain perfusion and activation in healthy older adults [58,59] (see Table 1 ). The antidepressant-like effects of blueberry extract might be mediated by the controlling monoaminergic systems and glucocorticoids, which are due to neuroprotective effects and antagonism of the 5-HT receptor [91]. Cyaniding-3-O-galactoside in blueberry can protect the central nervous system and can increase cognitive and behavioral 
function in the ageing process through enhancing the antioxidation capacity and altering stress signaling [92]. Blueberries anthocyanins and ethylacetate fraction of blueberry leaf were related with increased neuronal signaling in the brain, mediating memory function and glucose disposal as well as delay neurodegeneration $[60,93]$. The dogs proportion of cognitive improvements was higher in dogs fed with polyphenol extract from blueberry [94]. Phenolics from blueberry can reduce gastrointestinal infection for patients of cerebral venous thrombosis by improving antidepressant activity via upregulation of miR-155-regulated brain-induced neurotrophic factor [61] (see Table 1). Elevated neural activation with blueberry shows neurocognitive benefit in this at-risk population [95]. The neurocognitive benefits of blueberries are mostly due to anthocyanin, eicosapentaenoic acid, and docosahexaenoic acid [62]. Six berry extracts especially blueberry anthocyanins have the scavenging free radical trapping reactive carbonyl, glycossylation resistance, anti-A $\beta$ fibrillation, and microglial neuroprotective effects against Alzheimer's disease [96].

\subsection{Lung-Protective Properties and Functional Ingredients of Blueberry}

The anthocyanidin (cyanidin, malvidin, peonidin, petunidin, and delphinidin) mixture of blueberry can inhibit the growth and invasive nature of lung cancer cells, which has very good therapeutic potential in non-small-cell lung cancer treatment, especially preventive future recurrence and metastasis [2] (see Table 1). Water soluble compounds of blueberry enzymatic hydrolysis possess strong antioxidant activity against $\mathrm{H}_{2} \mathrm{O}_{2}$-induced cell damage of lung fibroblast [97].

\subsection{Strong Bones and Functional Ingredients of Blueberry}

Bone mineral density in the distal epiphysis was markedly different between blueberry and blackberry, and their anthocyanin composition will affect bone turnover [63]. The consumption of blueberries diet can prevent ovariectomy-induced bone loss in rats, its molecular mechanisms are promoted by myosin production which stimulates osteoblast differentiation and reduces interstitial cell senescence [98] (see Table 1). Blueberry can prevent bone loss to increase bone mineral density during bone metabolism, which may be due to lowered femoral mRNA levels of alkaline phosphatase and collagen type I [99].

\subsection{Enhance Immunological Effects and Functional Ingredients of Blueberry}

Blueberries alleviate immunomodulation, lighten oxidative stress, and inflammation in adults of the metabolic syndrome [100]. Polysaccharides $(100 \mathrm{mg} / \mathrm{kg} \cdot \mathrm{d})$ from blueberry can inhibit the tumor growth rate approximately $73.4 \%$, which could act as a good immunomodulator [64] (see Table 1). Blueberry can not only protect hepatocytes from oxidative stress and modulate the immune function of T-cells in mice, as well as induces the expression of three genes [101], but also enhances hepatic immunity in rats [102]. The immunoregulatory effect of flavonoids of blueberry leaves modulate the suppression of the TNF- $\alpha$ via and NF-KB signal pathways [65]. The obesity caused by a high-fat diet (HFD) can disrupt systemic immune function having deleterious impacts on T-cell hyperplasia and splenocyte immune abilities, however, dietary blueberry can improve T-cell and systemic immune function against HFD-obesity [103].

\subsection{Prevent Cardiovascular Diseases and Functional Ingredients of Blueberry}

Polyphenols in blueberry can regulate the vascular remodeling and improving the endothelial function both in smoker and in nonsmoker subjects [66]. Fermented blueberries with antihypertension properties can reduce the risk of cardiovascular diseases [104]. Blueberry-derived aglycone phenolic acids can lure Nrf2-controled antioxidant proteins in vascular endothelial cells [67]. Daily blueberry consumption can reduce blood pressure, aortic systolic pressure, arterial stiffness, diastolic pressure, and certain cancers in human due to increased nitric oxide production $[105,106]$ (see Table 1). Dietary flavonoid-rich blueberries are very effective in regulating primary hypertension, due to 
suppression of soluble angiotensin-converting enzyme activity [68]. Wild blueberries possess protective properties against cardiovascular disease [107].

\subsection{Blueberries can Improve Cognitive Decline, Functional Ingredients of Blueberry}

Polyphenols have the beneficial effect of ameliorating cognitive decline in aging adults, especially, a polyphenol-rich extract from blueberry increases the memory ability of people with a large variety of cognitive impairments [69] (see Table 1). Three-month intervention with $100 \mathrm{mg}$ blueberry extract can improve episodic memory performance and reduce cardiovascular risk factors over 6 months in an aged population [108]. The consumption of blueberry extracts regulates protein expression (e.g., dynamin 1) which is related to improved cognitive dysfunction in the hippocampus of APP/PS1 transgenic mice [109].

\section{Major Mechanisms and Structural Activity of Blueberry Compounds for Preventive Chronic Disease}

\subsection{Anthocyanins Mechanism and its Structural Activity}

Anthocyanins are a class of water-soluble flavonoids commonly consumed in the diet. Blueberry anthocyanins contribute to anticancer, anti-obesity, prevent degenerative diseases, anti-inflammation, protective properties for vision and liver, prevent heart diseases, antidiabetes, improve brain function, protective properties for the lung, and strong bones (see Table 1 and Figure 1). Blueberry is a super functional food with lots of health benefits due to its high levels of flavonoids. Flavanone 3-hydroxylase is a key regulatory enzyme of the flavonoid biosynthetic pathway for anthocyanin synthesis; anthocyanins are accumulated in fruits, whereas flavonols are found in leaves and stems [110]. Blueberry and malvidin for STAT-3 inhibitors in the oral cancer cell line SCC131, which regulates downstream targets that influence cell proliferation and apoptosis by abolishing the JAK/STAT-3 signaling pathway in a hamster model of oral oncogenesis [111]. Blueberry extracts exert anti-AML (acute myeloid leukemia) effects against myeloid leukemia cell lines, especially provoked by extracellular signal-regulated kinase (Erk) and protein kinase B (Akt) regulation within the leukemia stem cell subpopulation [112]. Blueberry anticancer effects associated with antioxidant and anti-inflammation, but controlling proliferation by regulating signal transduction. Functional ingredients of blueberry restrain the growth and metastasis of breast cancer cells by modulating the PI3K/AKT/NF-KB pathway [113]; the expression of caspase-9 and cytochrome $\mathrm{c}$ as well as the downregulation of the methylation of p53 of blueberry anthocyanins suppressed the proliferation and induced G2/M cell arrest and oral cancer cells apoptosis [114]. Blackberry anthocyanins and blueberry anthocyanins can ameliorate diet-induced obesity by alleviating oxidative stress and inflammation and quickening energy expenditure [115]. Blueberry peel extracts reduced weight and fat accumulation in obese rats by the downregulation of three genes and the reduction of phospho-Akt adipogenic factor in obese cells [116]. The antioxidant capacity of malvidin-3-glucoside in blueberry was stronger than that of malvidin-3-galactoside, glycosides improved the antioxidant capacity of malvidin to a great extent [38]. Eight-hundred-sixty-two transcription factors of 1236 transcripts in blueberry are involved in the antioxidant biosynthesis pathway of which about 92 expressed genes regulating anthocyanins in fruit during ripening [117]. The anti-inflammation mechanism of blueberry with malvidin-3-glucoside and malvidin-3-galactoside in endothelial cells was regulated by the nuclear factor-kappa B pathway [44]. Cyanidin-3-glucoside in blueberry has an ortho hydroxyl group for $B$ ring with a multitude of eye-protective effects in human retinal pigment epithelial cells [47]. Blueberry anthocyanins have a protective effect on eye health which restrains the development of age-related macular degeneration; the anthocyanins reduced the growth factor levels of vascular endothelial cells and activated Akt-signal pathways [118]. Blueberry anthocyanins can prevent diabetic retinopathy and protect human retinal capillary endothelial cells via antioxidant and anti-inflammatory mechanisms [119]. Blueberry anthocyanins have protective effects on CCl4 induced hepatic fibrosis, 
which associated to decrease ROS producing sources and oxidative damage, as well as the influence of pro-inflammatory cytokines, inhibit the activity of hepatic stellate cells, downregulation TIMP1, PCNA, Col-III, $\alpha$-SMA, and upregulation MMP-9 [120]. The action mechanism of oligomeric proanthocyanidin in blueberry leaves for resistant hepatitis $C$ virus is an inhibitor of hnRNP A2/B1 [78]. The blueberry probiotics could antagonize the nonalcoholic fatty liver disease via the phosphor-Janus kinase-1/phosphor-signal transducer and activator of transcription 3 signaling pathway [121]. The reno-protective effects of blueberry inhibit TLR4; however, the TLR4-MAPK signaling pathway is very important to renal structural injury and dysfunction in MetS [122]. The mechanisms of blueberry anthocyanins for preventive heart diseases was due to its anti-inflammation and antioxidation [52]. The antidiabetic effects of blueberry are attributed to anthocyanins and polyphenols, however their mechanism is an increase in insulin secretion for pelargonidin, reduction of insulin resistance for cyanidin-3-glucoside, and enhancement of $\beta$-cells regeneration [123]. The neuroprotective mechanism of anthocyanins in blueberry involves the regulation of the signal transduction processes and gene expression in the brain [124]; anthocyanins and flavanols from blueberries enter the brain and can prevent changes in spatial working memory in aged animals, which are associated with flavonoids on the extracellular signal-related kinase and cAMP-response element-binding protein as well as brain-derived neurotrophic factor pathway [125]. Cyaniding-3-O-galactoside in blueberry can improve hippocampal neuron survival, increase hippocampal phosphorylated extracellular pegulated protein kinases expression, prevent pyramidal cell layer damage, increase superoxide dismutase activity, and reduce malondialdehyde content in the brain [92]. Cyanidin and cyanidin-containing products from blueberry can prevent oxidative stress in neuronal cells by strengthening mitochondrial activity and reducing intracellular ROS output as well as lipid peroxidation induced by $\mathrm{H}_{2} \mathrm{O}_{2}$, especially upregulated by CAT and SOD activities [126]. Cyanidin-3-O-glucoside, with lung-protective effects on rats, is the most active anthocyanin in the blueberry, which relates the suppression of the NF- $\mathrm{B}$ s signaling pathway [127]. Flavonoids, especially saponarin and lutonarin, have a preventive and therapeutic role for chronic diseases and have an antidiabetic effect; regulate blood pressure; protect liver; have antidepressant activity, anticancer and anti-inflammatory activity, antioxidant and hypolipidemic effects prevent cardiovascular diseases, and have antihypoxia and anti-fatigue effects [128].

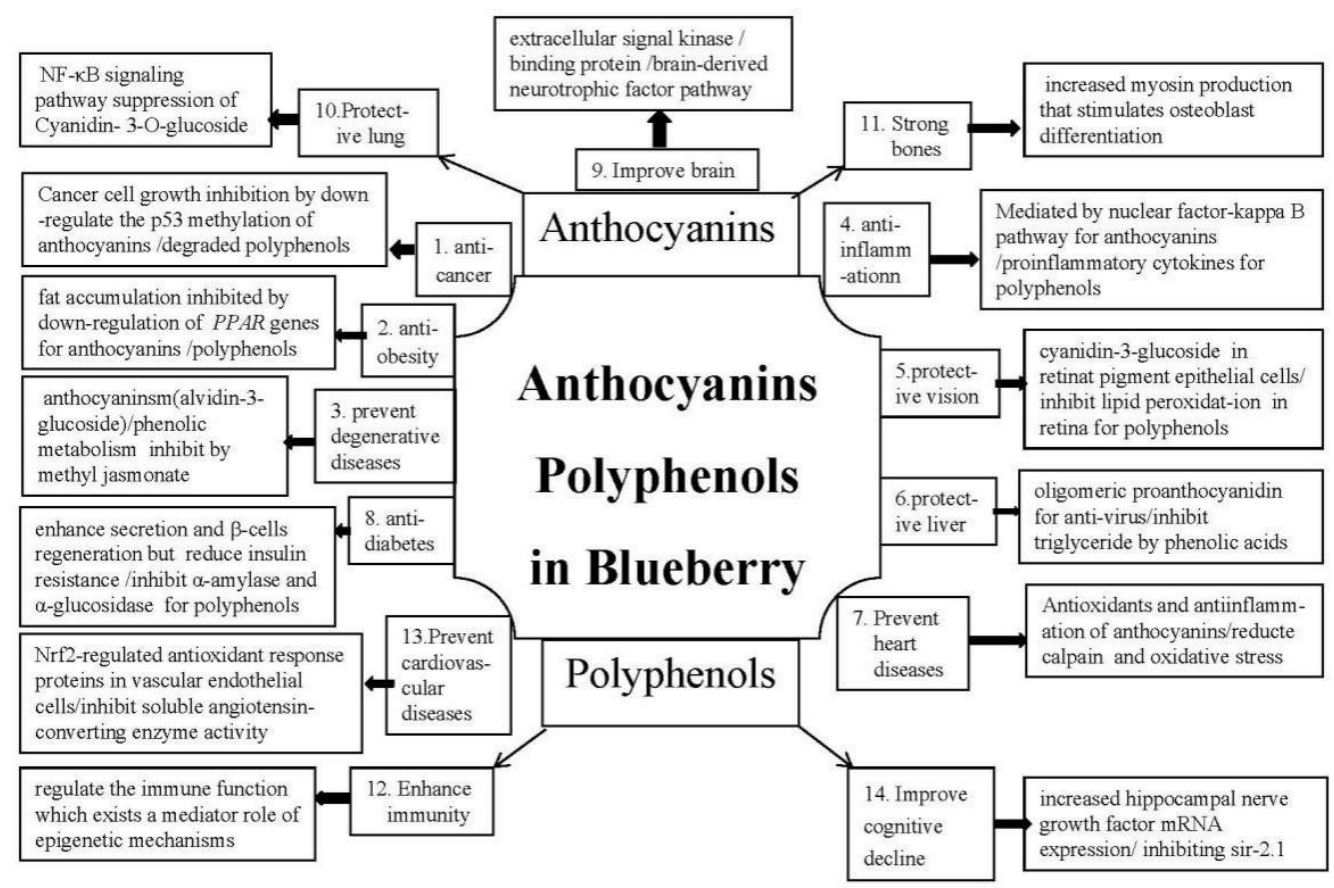

Figure 1. Possible mechanisms of functional ingredients in blueberry for preventive chronic disease. 


\subsection{Polyphenols Mechanism and its Structural Activity}

Polyphenols (including quercetin) contribute to anticancer and anti-obesity activity, prevent degenerative diseases, have anti-inflammation activity, have protective effects on vision and liver, prevent heart disease, have antidiabetes properties, enhance immunity, prevent cardiovascular diseases, and improve cognitive decline (see Table 1 and Figure 1). The quercetin in onion has preventive properties for chronic disease that include anticancer, cardiovascular and heart diseases, anti-inflammation, anti-obesity, antidiabetes, antimicrobial activities, neuroprotective, and immunological effects [129]. Wild blueberry polyphenols were degraded to some phenolic compounds after colonic fermentation, which have lower antioxidant activities and cancer cell growth inhibition effects [18]. Blueberry leaf extract, especially the polyphenol component, showed inhibited adipocyte differentiation and decreased lipid accumulation by downregulating gene expression of peroxisome proliferator-activated receptor (PPAR) and acetyl CoA carboxylase (ACCase) and upregulating the mRNA expression of adiponectin compared with the high-fat diet group [70]. Blueberry with antioxidative properties and even health effects are primarily due to anthocyanins and methyl jasmonate, however methyl jasmonate can promote gene expression and phenolic metabolism in blueberry [130]. The anti-inflammatory mechanism of blueberry polyphenols was revealed by regulating the pro-inflammatory cytokines balance of interleukin-1 $\beta$ (-6 and -12), especially blueberry polyphenols (10-200 $\mu \mathrm{g} / \mathrm{mL}$ ) had the most significant suppression of these three genes [22]. Blueberry polyphenols, especially quercetin, inhibit lipid peroxidation of unsaturated fatty acids in the retina so that antioxidants can nourish the eyes [131]. Wild Chinese blueberries can prevent nonalcoholic fatty liver disease, majorly due to the action of phenolic acids inhibiting triglyceride accumulation in HepG2 cells [131]. Blueberry polyphenols prevent heart diseases, which are associated with the reduction of calpain activity and oxidative stress [54]. Blueberry extract has hypoglycemic activity exerted by promoting the expression of GLUT-2 and PPAR $\gamma$ and controlling the inflammatory pathway; based on interaction between caffeoylquinic acid derivatives and quercetin glycosides [132]. Blueberry polyphenols and its fermented beverages can inhibit $\alpha$-amylase and $\alpha$-glucosidase of starch-degrading for type 2 diabetes management [133], however polyphenols can regulate the immune function which exists as a mediator role of epigenetic mechanisms [134]. The polyphenols slow aging in organisms from worm and fly to rodent and human [135]. Blueberries can protect the kidney against AKI by inhibiting toll-like receptor 4 and its succedent effect on inflammation and oxidative stress [136]. Polyphenols from blueberry, such as flavan-3-ols, anthocyanins, and resveratrol can modulate brain synaptic plasticity and cognitive processes especially preventing older memory deficits, based on increased mRNA expression of hippocampal nerve growth factor [137]. Functional polyphenols, such as $\alpha$-synuclein, have a therapeutic role for preventing protein aggregation related with neurodegeneration; however, Alaskan blueberries can alleviate pathologies of protein misfolding diseases by inhibiting sir-2.1 [138]. The memory protection of highbush blueberry vinegar can activate the brain-induced neurotrophic factor/cAMP response element restraining protein/serine-threonine kinase signaling [139].

\section{Conclusions}

Blueberry is one of the best functional foods, its total output was 629,720 tons in 2016 and its major distributors in the world are USA, Chile, Spain, and China. Blueberry is rich in flavonoids, polyphenols, phenolic acids, pyruvic acid, chlorogenic acid, and others. Blueberry is rich in anthocyanidins and polyphenols that are currently recommended among Chinese and international markets. Anthocyanidins in blueberry include cyanidin (red, violet, and blue change with $\mathrm{pH}$ ), pelargonidin (orange), malvidin (blue), petunidin (dark-red, purple), and delphinidin (blue, blue-red); its polyphenols include 3-glucoside/arabinoside/galactoside-based polymers of delphinidins, petunidins, peonidins, malvidins, and cyanidins; its antioxidant properties are major total phenolic, quinic, chlorogenic acids, and rutin. The systematic review summarized describes the mechanisms of anthocyanidin and polyphenols from blueberry for preventive chronic diseases. 
Blueberry anthocyanins have a lot of health benefits for human beings, which include anticancer, anti-obesity, prevent degenerative diseases, anti-inflammation, protective vision, protective liver, prevent heart diseases, antidiabetes, improve brain, and protective lung. Anthocyanins mechanism of blueberry for preventive chronic diseases are major as follows: The anticancer effect of anthocyanins is mediated by abolishing the JAK/STAT-3 signaling pathway and modulating the PI3K/AKT/Erk/Akt/P53/NF-KB pathway. The anti-obesity effect of anthocyanins is mediated by the downregulation of three genes and the reduction of the phospho-Akt adipogenic factor. Prevent degenerative diseases associated with stronger antioxidant capacity of malvidin-3-glucoside in blueberry; anti-inflammation of anthocyanins regulated by the nuclear factor-kappa B pathway; protective vision of cyanidin-3-glucoside in retinal pigment epithelial cells can reduce the growth factor of vascular endothelial cell and activated Akt-signaling, protective liver of anthocyanins is down-regulation TIMP1, PCNA, Col-III, $\alpha$-SMA, and upregulation MMP-9 as well as an inhibitor of hnRNP A2/B1; prevent heart diseases of anthocyanins associated with anti-inflammation and antioxidation; the antidiabetic effect of anthocyanins increases the insulin secretion and reduces insulin resistance as well as enhances $\beta$-cell regeneration. The protective effect of anthocyanins on the brain is mediated by the extracellular signal-related kinase and cAMP-response element-binding protein, as well as brain-derived neurotrophic factor pathway and gene expression in brain. The protective effect of anthocyanins with relation to the lung is mediated by the suppression of the NF-KB signaling pathway.

Blueberry polyphenols have been shown to be beneficial to human health, and have beneficial properties which include anticancer, anti-obesity, prevention of degenerative diseases, anti-inflammation, protective effect on vision and liver, prevention of heart disease, antidiabetes, enhanced immune function, prevention of cardiovascular diseases, and improved cognitive decline. The mechanisms of polyphenols for the prevention of chronic diseases are as follows. Anticancer: polyphenols inhibit cancer cell growth by degraded polyphenols. Anti-obesity: polyphenols downregulate PPAR and ACCase gene expression and upregulate the mRNA expression. The prevention of degenerative diseases is associated with the gene expression and phenolic metabolism. The anti-inflammatory properties of polyphenols are mediated by the regulation of the pro-inflammatory cytokine balance and suppression of three genes. The protective vision property of polyphenols is mediated by the inhibition of lipid peroxidation in the retina. The protective liver property of polyphenols is mediated by the inhibition of triglyceride accumulation in HepG2 cells. The preventative effect on heart disease is associated with a reduction in calpain activity and oxidative stress. The antidiabetic effect of polyphenols is mediated by the inhibition of $\alpha$-amylase and $\alpha$-glucosidase, promoting the expression of GLUT-2 and PPAR $\gamma$ that control the inflammatory pathway. The enhanced immunity of polyphenols is affected via a mediator role of epigenetic mechanisms. The prevention of cardiovascular diseases by polyphenols is mediated by the inhibition of soluble angiotensin-converting enzyme activity. The improvement in cognitive decline of polyphenols in caused by an increase in mRNA expression of the hippocampal nerve growth factor and restraining protein/serine-threonine kinase signaling.

Although functional ingredients in blueberry for preventive chronic diseases seem a complicated task and functional foods for therapeutic interventions may open new avenues, a further search of scientific evidence, from more carefully controlled longer-duration observational, animal, and human trials, especially anthocyanins and polyphenols in blueberry extracts, demonstrates the health effects for the treatment of chronic diseases. Dietary blueberry is one of the most exciting potential natural sources for developing functional foods and novel drugs with improved efficiency, efficacy, and safety. These data supported that anthocyanidins and polyphenols from blueberry are very important for the prevention of chronic diseases.

This review provides useful information for future research, especially anthocyanidins and polyphenols for the prevention or treatment of chronic diseases. In addition, it will be interesting to understand the interconnection between functional ingredients in blueberry and preventive chronic 
diseases in clinical trials. Further studies unravel the therapeutic role of major compounds of other berries for chronic disease. This review may be used as a starting point for novel nutraceuticals, functional foods, and drugs for blueberry to improve the prognosis of chronic diseases.

Funding: This research was funded by the Science and Technology to Benefit the People from Yunnan Provincial Scientific and Technology Department (2014RA060), the scientific research foundation of Yunnan Provincial Department of Education (2017YJS091), and China Agriculture Research System (CARS-05).

Acknowledgments: The authors thank Jahid Hasan from Bangladesh for revisions of the grammar mistakes for the manuscript.

Conflicts of Interest: The authors declare no conflicts of interest.

\section{References}

1. Skrovankova, S.; Sumczynski, D.; Mlcek, J.; Jurikova, T.; Sochor, J. Bioactive compounds and antioxidant activity in different types of berries. Int. J. Mol. Sci. 2015, 16, 24673-24706. [CrossRef] [PubMed]

2. Kausar, H.; Jeyabalan, J.; Aqil, F.; Chabba, D.; Sidana, J.; Singh, I.P.; Gupta, R.C. Berry anthocyanidins synergistically suppress growth and invasive potential of human non-small-cell lung cancer cells. Cancer Lett. 2012, 325, 54-62. [CrossRef] [PubMed]

3. Zeng, Y.W.; Du, J.; Pu, X.Y.; Yang, J.Z.; Yang, T.; Yang, S.; Yang, X. Coevolution between cancer activities and food structure of human being from southwest China. BioMed Res. Int. 2015, 2015, 497934. [CrossRef] [PubMed]

4. Ayoub, M.; de Camargo, A.C.; Shahidi, F. Antioxidants and bioactivities of free, esterified and insoluble-bound phenolics from berry seed meals. Food Chem. 2016, 197, 221-232. [CrossRef] [PubMed]

5. Marhuenda, J.; Alemán, M.D.; Gironés-Vilaplana, A.; Pérez, A.; Caravaca, G.; Figueroa, F.; Mulero, J.; Zafrilla, P. Phenolic composition, antioxidant activity, and in vitro availability of four different berries. J. Chem. 2016, 2016, 5194901. [CrossRef]

6. Ciric, A.; Jelikic-Stankov, M.; Cvijovic, M.; Djurdjevic, P. Statistical optimization of an RP-HPLC method for the determination of selected flavonoids in berry juices and evaluation of their antioxidant activities. Biomed. Chromatogr. 2018, 32, e4150. [CrossRef] [PubMed]

7. Cásedas, G.; Les, F.; Gómez-Serranillos, M.P.; Smith, C.; López, V. Anthocyanin profile, antioxidant activity and enzyme inhibiting properties of blueberry and cranberry juices: A comparative study. Food Funct. 2017, 8, 4187-4193. [CrossRef] [PubMed]

8. Cortez, R.; Luna-Vital, D.A.; Margulis, D.; Gonzalez de Mejia, E. Natural pigments: Stabilization methods of anthocyanins for food applications. Compr. Rev. Food Sci. Food Saf. 2017, 16, 180-198. [CrossRef]

9. Chen, C.F.; Li, Y.D.; Xu, Z. Chemical principles and bioactivities of blueberry. Yao Xue Xue Bao 2010, 45, 422-429. (In Chinese) [PubMed]

10. Rowland, L.J.; Alkharouf, N.; Darwish, O.; Ogden, E.L.; Polashock, J.J.; Bassil, N.V.; Main, D. Generation and analysis of blueberry transcriptome sequences from leaves, developing fruit, and flower buds from cold acclimation through deacclimation. BMC Plant Biol. 2012, 12, 46. [CrossRef] [PubMed]

11. Ravoori, S.; Vadhanam, M.V.; Aqil, F.; Gupta, R.C. Inhibition of estrogen-mediated mammary tumorigenesis by blueberry and black raspberry. J. Agric. Food Chem. 2012, 60, 5547-5555. [CrossRef] [PubMed]

12. Wu, T.; Tang, Q.; Gao, Z.; Yu, Z.; Song, H.; Zheng, X.; Chen, W. Blueberry and mulberry juice prevent obesity development in C57BL/ 6 mice. PLoS ONE 2013, 8, e77585. [CrossRef] [PubMed]

13. Ren, T.; Huang, C.; Cheng, M. Dietary Blueberry and bifidobacteria attenuate nonalcoholic fatty liver disease in rats by affecting SIRT1-mediated signaling pathway. Oxid. Med. Cell. Longev. 2014, 2014, 469059. [CrossRef] [PubMed]

14. Lin, Z.; Fischer, J. Wicker, L. Intermolecular binding of blueberry pectin-rich fractions and anthocyanin. Food Chem. 2016, 194, 986-993. [CrossRef] [PubMed]

15. Rahal, O.M.; Pabona, J.M.; Kelly, T.; Huang, Y.; Hennings, L.J.; Prior, R.L.; Al-Dwairi, A.; Simmen, F.A.; Simmen, R.C. Suppression of Wnt1-induced mammary tumor growth and lower serum insulin in offspring exposed to maternal blueberry diet suggest early dietary influence on developmental programming. Carcinogenesis 2013, 34, 464-474. [CrossRef] [PubMed] 
16. Kraujalytė, V.; Venskutonis, P.R.; Pukalskas, A.; Česonienė, L.; Daubaras, R. Antioxidant properties, phenolic composition and potentiometric sensor array evaluation of commercial and new blueberry (Vaccinium corymbosum) and bog blueberry (Vaccinium uliginosum) genotypes. Food Chem. 2015, 188, 583-590. [CrossRef] [PubMed]

17. Li, B.; Yongku, L.; Wang, X.; Wang, F.; Wang, X.; Wang, Y.; Meng, X. Simultaneous separation and determination of organic acids in blueberry juices by capillary electrophoresis-electrospray ionization mass spectrometry. J. Food Sci. Technol. 2015, 52, 5228-5235. [CrossRef] [PubMed]

18. Correa-Betanzo, J.; Allen-Vercoe, E.; McDonald, J.; Schroeter, K.; Corredig, M.; Paliyath, G. Stability and biological activity of wild blueberry (Vaccinium angustifolium) polyphenols during simulated in vitro gastrointestinal digestion. Food Chem. 2014, 165, 522-531. [CrossRef] [PubMed]

19. Zu, X.Y.; Zhang, Z.Y.; Zhang, X.W.; Yoshioka, M.; Yang, Y.N.; Li, J. Anthocyanins extracted from Chinese blueberry (Vaccinium uliginosum L.) and its anticancer effects on DLD-1 and COLO205 cells. Chin. Med. J. 2010, 123, 2714-2719. [PubMed]

20. Pertuzatti, P.B.; Barcia, M.T.; Rodrigues, D.; da Cruz, P.N.; Hermosín-Gutiérrez, I.; Smith, R.; Godoy, H.T. Antioxidant activity of hydrophilic and lipophilic extracts of Brazilian blueberries. Food Chem. 2014, 164, 81-88. [CrossRef] [PubMed]

21. Lee, S.G.; Vance, T.M.; Nam, T.G.; Kim, D.O.; Koo, S.I.; Chun, O.K. Contribution of anthocyanin composition to total antioxidant capacity of berries. Plant Foods Hum. Nutr. 2015, 70, 427-432. [CrossRef] [PubMed]

22. Bobinaitè, R.; Pataro, G.; Lamanauskas, N.; Šatkauskas, S.; Viškelis, P.; Ferrari, G. Application of pulsed electric field in the production of juice and extraction of bioactive compounds from blueberry fruits and their by-products. J. Food Sci. Technol. 2015, 52, 5898-58905. [CrossRef] [PubMed]

23. Davidson, K.T.; Zhu, Z.; Balabanov, D.; Zhao, L.; Wakefield, M.R.; Bai, Q.; Fang, Y. Beyond conventional medicine-A look at blueberry, a cancer-fighting superfruit. Pathol. Oncol. Res. 2017, 24, 733-738. [CrossRef] [PubMed]

24. Davidson, K.T.; Zhu, Z.; Bai, Q.; Xiao, H.; Wakefield, M.R.; Fang, Y. Blueberry as a potential radiosensitizer for treating cervical cancer. Pathol. Oncol. Res. 2017. [CrossRef] [PubMed]

25. Faria, A.; Pestana, D.; Teixeira, D.; de Freitas, V.; Mateus, N.; Calhau, C. Blueberry anthocyanins and pyruvic acid adducts: Anticancer properties in breast cancer cell lines. Phytother. Res. 2010, 24, 1862-1869. [CrossRef] [PubMed]

26. Bunea, A.; Rugină, D.; Sconţa, Z.; Pop, R.M.; Pintea, A.; Socaciu, C.; Tăbăran, F.; Grootaert, C.; Struijs, K.; VanCamp, J. Anthocyanin determination in blueberry extracts from various cultivars and their antiproliferative and apoptotic properties in B16-F10 metastatic murine melanoma cells. Phytochemistry 2013, 95, 436-444. [CrossRef] [PubMed]

27. Zhou, F.; Wang, T.; Zhang, B.; Zhao, H. Addition of sucrose during the blueberry heating process is good or bad? Evaluating the changes of anthocyanins/anthocyanidins and the anticancer ability in HepG-2 cells. Food Res. Int. 2018, 107, 509-517. [CrossRef] [PubMed]

28. Zhao, M.; Wang, P.; Zhu, Y.; Liu, X.; Hu, X.; Chen, F. The chemoprotection of a blueberry anthocyanin extract against the acrylamide-induced oxidative stress in mitochondria: Unequivocal evidence in mice liver. Food Funct. 2015, 6, 3006-3012. [CrossRef] [PubMed]

29. Chen, G.; Xu, Z.; Chang, G.; Hou, J.; Hu, L.; Zhang, Y.; Yu, D.; Li, B.; Chang, S.; Xie, Y.; et al. The blueberry component pterostilbene has potent anti-myeloma activity in bortezomib-resistant cells. Oncol. Rep. 2017, 38, 488-496. [CrossRef] [PubMed]

30. Minker, C.; Duban, L.; Karas, D.; Järvinen, P.; Lobstein, A.; Muller, C.D. Impact of procyanidins from different berries on caspase 8 activation in colon cancer. Oxid. Med. Cell. Longev. 2015, 2015, 154164. [CrossRef] [PubMed]

31. Håkansson, A.; Bränning, C.; Molin, G.; Adawi, D.; Hagslätt, M.-L.; Jeppsson, B.; Nyman, M.; Ahrné, S. Blueberry husks and probiotics attenuate colorectal inflammation and oncogenesis, and liver injuries in rats exposed to cycling DSS-treatment. PLoS ONE 2012, 7, e33510. [CrossRef] [PubMed]

32. Kim, M.; Na, H.; Kasai, H.; Kawai, K.; Li, Y.S.; Yang, M. Comparison of blueberry (Vaccinium spp.) and vitamin C via antioxidative and epigenetic effects in human. J. Cancer Prev. 2017, 22, 174-181. [CrossRef] [PubMed] 
33. Wang, E.; Liu, Y.; Xu, C.; Liu, J. Antiproliferative and proapoptotic activities of anthocyanin and anthocyanidin extracts from blueberry fruits on B16-F10 melanoma cells. Food Nutr. Res. 2017, 61, 1325308. [CrossRef] [PubMed]

34. Lin, W.; Li, Z. Blueberries inhibit cyclooxygenase-1 and cyclooxygenase-2 activity in human epithelial ovarian cancer. Oncol. Lett. 2017, 13, 4897-4904. [CrossRef] [PubMed]

35. Garcia-Diaz, D.F.; Johnson, M.H.; de Mejia, E.G. Anthocyanins from fermented berry beverages inhibit inflammation-related adiposity response in vitro. J. Med. Food 2015, 18, 489-496. [CrossRef] [PubMed]

36. Moghe, S.S.; Juma, S.; Imrhan, V.; Vijayagopal, P. Effect of blueberry polyphenols on 3T3-F442A preadipocyte differentiation. J. Med. Food 2012, 15, 448-452. [CrossRef] [PubMed]

37. Diaconeasa, Z.; Leopold, L.; Rugină, D.; Ayvaz, H.; Socaciu, C. Antiproliferative and antioxidant properties of anthocyanin rich extracts from blueberry and blackcurrant juice. Int. J. Mol. Sci. 2015, 16, 2352-2365. [CrossRef] [PubMed]

38. Huang, W.Y.; Zhu, Y.M.; Li, C.Y.; Sui, Z.Q.; Min, W.H. Effect of blueberry anthocyanins malvidin and glycosides on the antioxidant properties in endothelial cells. Oxid. Med. Cell. Longev. 2016, 2016, 1591803. [CrossRef] [PubMed]

39. Kim, J.G.; Kim, H.L.; Kim, S.J.; Park, K.S. Fruit quality, anthocyanin and total phenolic contents, and antioxidant activities of 45 blueberry cultivars grown in Suwon, Korea. J. Zhejiang Univ. Sci. B 2013, 14, 793-799. [CrossRef] [PubMed]

40. Kang, J.; Thakali, K.M.; Jensen, G.S.; Wu, X. Phenolic acids of the two major blueberry species in the US Market and their antioxidant and anti-inflammatory activities. Plant Foods Hum. Nutr. 2015, 70, 56-62. [CrossRef] [PubMed]

41. Li, C.; Feng, J.; Huang, W.Y.; An, X.T. Composition of polyphenols and antioxidant activity of rabbiteye blueberry (Vaccinium ashei) in Nanjing. J. Agric. Food Chem. 2013, 61, 523-531. [CrossRef] [PubMed]

42. Ben Lagha, A.; Dudonné, S.; Desjardins, Y.; Grenier, D. Wild blueberry (Vaccinium angustifolium Ait.) polyphenols target Fusobacterium nucleatum and the host inflammatory response: Potential innovative molecules for treating periodontal diseases. J. Agric. Food Chem. 2015, 63, 6999-7008. [CrossRef] [PubMed]

43. McAnulty, L.S.; Nieman, D.C.; Dumke, C.L.; Shooter, L.A.; Henson, D.A.; Utter, A.C.; Milne, G.; McAnulty, S.R. Effect of blueberry ingestion on natural killer cell counts, oxidative stress, and inflammation prior to and after $2.5 \mathrm{~h}$ of running. Appl. Physiol. Nutr. Metabl. 2011, 36, 976-984. [CrossRef] [PubMed]

44. Huang, W.Y.; Liu, Y.M.; Wang, J.; Wang, X.N.; Li, C.Y. Anti-inflammatory effect of the blueberry anthocyanins malvidin-3-glucoside and malvidin-3-galactoside in endothelial cells. Molecules 2014, 19, 12827-12841. [CrossRef] [PubMed]

45. Ben Lagha, A.; LeBel, G.; Grenier, D. Dual action of highbush blueberry proanthocyanidins on Aggregatibacter actinomycetemcomitans and the host inflammatory response. BMC Complem. Altern. Med. 2018, 18, 10. [CrossRef] [PubMed]

46. Kalt, W.; McDonald, J.E.; Fillmore, S.A.; Tremblay, F. Blueberry effects on dark vision and recovery after photobleaching: Placebo-controlled crossover studies. J. Agric. Food Chem. 2014, 62, 11180-11189. [CrossRef] [PubMed]

47. Wang, Y.; Zhang, D.; Liu, Y.; Wang, D.; Liu, J.; Ji, B. The protective effects of berry-derived anthocyanins against visible light-induced damage in human retinal pigment epithelial cells. J. Sci. Food Agri. 2015, 95, 936-944. [CrossRef] [PubMed]

48. Liu, Y.; Zhang, D.; Hu, J.; Liu, G.; Chen, J.; Sun, L.; Jiang, Z.; Zhang, X.; Chen, Q.; Ji, B. Visible light-induced lipid peroxidation of unsaturated fatty acids in the retina and the inhibitory effects of blueberry polyphenols. J. Agric. Food Chem. 2015, 63, 9295-9305. [CrossRef] [PubMed]

49. Srovnalova, A.; Svecarova, M.; Zapletalova, M.K.; Anzenbacher, P.; Bachleda, P.; Anzenbacherova, E.; Dvorak, Z. Effects of anthocyanidins and anthocyanins on the expression and catalytic activities of CYP2A6, CYP2B6, CYP2C9, and CYP3A4 in primary human hepatocytes and human liver microsomes. J. Agric. Food Chem. 2014, 62, 789-797. [CrossRef] [PubMed]

50. Ferlemi, A.-V.; Mermigki, P.G.; Makri, O.E.; Anagnostopoulos, D.; Koulakiotis, N.S.; Margarity, M.; Tsarbopoulos, A.; Georgakopoulos, C.D.; Lamari, F.N. Cerebral area differential redox response of neonatal rats to selenite-induced oxidative stress and to concurrent administration of highbush blueberry leaf polyphenols. Neurochem. Res. 2015, 40, 2280-2292. [CrossRef] [PubMed] 
51. Zhan, W.; Liao, X.; Xie, R.J.; Tian, T.; Yu, L.; Liu, X.; Liu, J.; Li, P.; Han, B.; Yang, T.; et al. The effects of blueberry anthocyanins on histone acetylation in rat liver fibrosis. Oncotarget 2017, 8, 96761-96773. [CrossRef] [PubMed]

52. Liu, Y.; Tan, D.; Shi, L.; Liu, X.; Zhang, Y.; Tong, C.; Song, D.; Hou, M. Blueberry anthocyanins-enriched extracts attenuate cyclophosphamide-induced cardiac injury. PLoS ONE 2015, 10, e0127813. [CrossRef] [PubMed]

53. Khanal, R.C.; Howard, L.R.; Brownmiller, C.R.; Prior, R.L. Influence of extrusion processing on procyanidin composition and total anthocyanin contents of blueberry pomace. J. Food Sci. 2009, 74, H52-H58. [CrossRef] [PubMed]

54. Louis, X.L.; Thandapilly, S.J.; Kalt, W.; Vinqvist-Tymchuk, M.; Aloud, B.M.; Raj, P.; Yu, L.; Le, H.; Netticadan, T. Blueberry polyphenols prevent cardiomyocyte death by preventing calpain activation and oxidative stress. Food Funct. 2014, 5, 1785-1794. [CrossRef] [PubMed]

55. Bharat, D.; Cavalcanti, R.R.M.; Petersen, C.; Begaye, N.; Cutler, B.R.; Costa, M.M.A.; Ramos, R.K.L.G.; Ferreira, M.R.; Li, Y.; Bharath, L.P.; et al. Blueberry metabolites attenuate lipotoxicity-induced endothelial dysfunction. Mol. Nutr. Food Res. 2017, 62. [CrossRef] [PubMed]

56. Liu, J.; Gao, F.; Ji, B.; Wang, R.; Yang, J.; Liu, H.; Zhou, F. Anthocyanins-rich extract of wild Chinese blueberry protects glucolipotoxicity -induced INS832/13 $\beta$-cell against dysfunction and death. J. Food Sci. Technol. 2015, 52, 3022-3029. [CrossRef] [PubMed]

57. Bell, L.; Lamport, D.J.; Butler, L.T.; Williams, C.M. A study of glycaemic effects following acute anthocyanin-rich blueberry supplementation in healthy young adults. Food Funct. 2017, 8, 3104-3110. [CrossRef] [PubMed]

58. Bowtell, J.L.; Aboo-Bakkar, Z.; Conway, M.; Adlam, A.R.; Fulford, J. Enhanced task related brain activation and resting perfusion in healthy older adults after chronic blueberry supplementation. Appl. Physiol. Nutr. Metab. 2017, 42, 773-779. [CrossRef] [PubMed]

59. Miller, M.G.; Hamilton, D.A.; Joseph, J.A.; Shukitt-Hale, B. Dietary blueberry improves cognition among older adults in a randomized, double-blind, placebo-controlled trial. Eur. J. Nutr. 2017, 57, 1169-1180. [CrossRef] [PubMed]

60. Krikorian, R.; Shidler, M.D.; Nash, T.A.; Kalt, W.; Vinqvist-Tymchuk, M.R.; Shukitt-Hale, B.; Joseph, J.A. Blueberry supplementation improves memory in older adults. J. Agric. Food Chem. 2010, 58, 3996-4000. [CrossRef] [PubMed]

61. Xu, N.; Meng, H.; Liu, T.; Feng, Y.; Qi, Y.; Zhang, D.; Wang, H. Blueberry phenolics reduce gastrointestinal infection of patients with cerebral venous thrombosis by improving depressant-induced autoimmune disorder via miR-155-mediated brain-derived neurotrophic factor. Front. Pharmacol. 2017, 8, 853. [CrossRef] [PubMed]

62. McNamara, R.K.; Kalt, W.; Shidler, M.D.; McDonald, J.; Summer, S.S.; Stein, A.L.; Stover, A.N.; Krikorian, R. Cognitive response to fish oil, blueberry, and combined supplementation in older adults with subjective cognitive impairment. Neurobiol. Aging 2018, 64, 147-156. [CrossRef] [PubMed]

63. Lee, S.G.; Kim, B.; Soung do, Y.; Vance, T.; Lee, J.S.; Lee, J.Y.; Koo, S.I.; Kim, D.O.; Drissi, H.; Chun, O.K. Relationship between oxidative stress and bone mass in obesity and effects of berry supplementation on bone remodeling in obese male mice: An exploratory study. J. Med. Food 2015, 18, 476-482. [CrossRef] [PubMed]

64. Sun, X.; Liu, N.; Wu, Z.; Feng, Y.; Meng, X. Anti-tumor activity of a polysaccharide from blueberry. Molecules 2015, 20, 3841-3853. [CrossRef] [PubMed]

65. Shi, D.; Xu, M.; Ren, M.; Pan, E.; Luo, C.; Zhang, W.; Tang, Q. Immunomodulatory effect of flavonoids of blueberry (Vaccinium corymbosum L.) leaves via the NF-kB signal pathway in LPS-stimulated RAW 264.7 cells. J. Immunol. Res. 2017, 2017, 5476903. [CrossRef] [PubMed]

66. Del Bo', C.; Deon, V.; Campolo, J.; Lanti, C.; Parolini, M.; Porrini, M.; Klimis-Zacas, D.; Riso, P. A serving of blueberry (V. corymbosum) acutely improves peripheral arterial dysfunction in young smokers and nonsmokers: Two randomized, controlled, crossover pilot studies. Food Funct. 2017, 8, 4108-4117. [CrossRef] [PubMed]

67. Tang, J.S.; Vissers, M.C.M.; Anderson, R.F.; Sreebhavan, S.; Bozonet, S.M.; Scheepens, A.; Melton, L.D. Bioavailable blueberry-derived phenolic acids at physiological concentrations enhance Nrf2-regulated antioxidant pesponses in human vascular endothelial cells. Mol. Nutr. Food Res. 2017, 62. [CrossRef] 
68. Wiseman, W.; Egan, J.M.; Slemmer, J.E.; Shaughnessy, K.S.; Ballem, K.; Gottschall-Pass, K.T.; Sweeney, M.I. Feeding blueberry diets inhibits angiotensin II-converting enzyme (ACE) activity in spontaneously hypertensive stroke-prone rats. Can. J. Physiol. Pharmacol. 2011, 89, 67-71. [CrossRef] [PubMed]

69. Bensalem, J.; Dudonné, S.; Etchamendy, N.; Pellay, H.; Amadieu, C.; Gaudout, D.; Dubreuil, S.; Paradis, M.E.; Pomerleau, S.; Capuron, L.; et al. Polyphenols from grape and blueberry improve episodic memory in healthy elderly with lower level of memory performance: A bicentric double-blind, randomized, placebo-controlled clinical study. J. Gerontol. 2018. [CrossRef] [PubMed]

70. Lee, I.C.; Kim, D.Y.; Choi, B.Y. Antioxidative activity of blueberry leaf extract prevents high-fat diet-induced obesity in C57BL/6 mice. J. Cancer Prev. 2014, 19, 209-215. [CrossRef] [PubMed]

71. Reyes-Farias, M.; Vasquez, K.; Ovalle-Marin, A.; Fuentes, F.; Parra, C.; Quitral, V.; Jimenez, P.; Garcia-Diaz, D.F. Chilean native fruit extracts inhibit inflammation linked to the pathogenic interaction between adipocytes and macrophages. J. Med. Food 2015, 18, 601-608. [CrossRef] [PubMed]

72. Vendrame, S.; Daugherty, A.; Kristo, A.S.; Klimis-Zacas, D. Wild blueberry (Vaccinium angustifolium)-enriched diet improves dyslipidaemia and modulates the expression of genes related to lipid metabolism in obese Zucker rats. Br. J. Nutr. 2014, 111, 194-200. [CrossRef] [PubMed]

73. Aranaz, P.; Romo-Hualde, A.; Zabala, M.; Navarro-Herrera, D.; Ruiz de Galarreta, M.; Gil, A.G.; Martinez, J.A.; Milagro, F.I.; González-Navarro, C.J. Freeze-dried strawberry and blueberry attenuates diet-induced obesity and insulin resistance in rats by inhibiting adipogenesis and lipogenesis. Food Funct. 2017, 8, 3999-4013. [CrossRef] [PubMed]

74. Wu, Y.; Zhou, Q.; Chen, X.Y.; Li, X.; Wang, Y.; Zhang, J.L. Comparison and screening of bioactive phenolic compounds in different blueberry cultivars: Evaluation of anti-oxidation and $\alpha$-glucosidase inhibition effect. Food Res. Int. 2017, 100, 312-324. [CrossRef] [PubMed]

75. Lee, Y.M.; Yoon, Y.; Yoon, H.; Park, H.M.; Song, S.; Yeum, K.J. Dietary anthocyanins against obesity and inflammation. Nutrients 2017, 9, 1089. [CrossRef] [PubMed]

76. Vendrame, S.; Daugherty, A.; Kristo, A.S.; Riso, P.; Klimis-Zacas, D. Wild blueberry (Vaccinium angustifolium) consumption improves inflammatory status in the obese Zucker rat model of the metabolic syndrome. J. Nutr. Biochem. 2013, 24, 1508-1512. [CrossRef] [PubMed]

77. Liu, Y.; Song, X.; Han, Y.; Zhou, F.; Zhang, D.; Ji, B.; Hu, J.; Lv, Y.; Cai, S.; Wei, Y.; et al. Identification of anthocyanin components of wild Chinese blueberries and amelioration of light-induced retinal damage in pigmented rabbit using whole berries. J. Agric. Food Chem. 2011, 59, 356-363. [CrossRef] [PubMed]

78. Ishida, Y.; Takeshita, M.; Kataoka, H. Functional foods effective for hepatitis C: Identification of oligomeric proanthocyanidin and its action mechanism. World J. Hepatol. 2014, 6, 870-879. [CrossRef] [PubMed]

79. Zhao, M.; Liu, X.; Luo, Y.; Guo, H.; Hu, X.; Chen, F. Evaluation of protective effect of freeze-dried strawberry, grape, and blueberry powder on acrylamide toxicity in mice. J. Food Sci. 2015, 80, H869-H874. [CrossRef] [PubMed]

80. Gong, P.; Chen, F.X.; Wang, L.; Wang, J.; Jin, S.; Ma, Y.M. Protective effects of blueberries (Vaccinium corymbosum L.) extract against cadmium-induced hepatotoxicity in mice. Environ. Toxicol. Pharmacol. 2014, 37, 1015-1027. [CrossRef] [PubMed]

81. Ozcelik, E.; Uslu, S.; Burukoglu, D.; Musmul, A. Chitosan and blueberry treatment induces arginase activity and inhibits nitric oxide production during acetaminophen-induced hepatotoxicity. Pharmacogn. Mag. 2014, 10, S217-S224. [CrossRef] [PubMed]

82. Vendrame, S.; Zhao, A.; Merrow, T.; Klimis-Zacas, D. The effects of wild blueberry consumption on plasma markers and gene expression related to glucose metabolism in the obese Zucker rat. J. Med. Food 2015, 18, 619-624. [CrossRef] [PubMed]

83. Cutler, B.R.; Gholami, S.; Chua, J.S.; Kuberan, B.; Anandh Babu, P.V. Blueberry metabolites restore cell surface glycosaminoglycans and attenuate endothelial inflammation in diabetic human aortic endothelial cells. Int. J. Cardiol. 2018, 261, 155-158. [CrossRef] [PubMed]

84. Nemes-Nagy, E.; Szocs-Molnár, T.; Dunca, I.; Balogh-Sămărghiţan, V.; Hobai, S.; Morar, R.; Pusta, D.L.; Crăciun, E.C. Effect of a dietary supplement containing blueberry and sea buckthorn concentrate on antioxidant capacity in type 1 diabetic children. Acta Physiol. Hung. 2008, 95, 383-393. [CrossRef] [PubMed] 
85. Elks, C.M.; Terrebonne, J.D.; Ingram, D.K.; Stephens, J.M. Blueberries improve glucose tolerance without altering body composition in obese postmenopausal mice. Obesity 2015, 23, 573-580. [CrossRef] [PubMed]

86. DeFuria, J.; Bennett, G.; Strissel, K.J.; Perfield, J.W.; Milbury, P.E.; Greenberg, A.S.; Obin, M.S. Dietary blueberry attenuates whole-body insulin resistance in high fat-fed mice by reducing adipocyte death and its inflammatory sequelae. J. Nutr. 2009, 139, 1510-1516. [CrossRef] [PubMed]

87. Lee, S.; Keirsey, K.I.; Kirkland, R.; Grunewald, Z.I.; Fischer, J.G.; de La Serre, C.B. Blueberry supplementation influences the gut microbiota, inflammation, and insulin resistance in high-fat-diet-fed rats. J. Nutr. 2018, 148, 209-219. [CrossRef] [PubMed]

88. Çoban, J.; Doğan-Ekici, I.; Aydın, A.F.; Betül-Kalaz, E.; Doğru-Abbasoğlu, S.; Uysal, M. Blueberry treatment decreased D-galactose-induced oxidative stress and brain damage in rats. Metab. Brain Dis. 2015, 30, 793-802. [CrossRef] [PubMed]

89. Liu, F.; Wang, L.; Gu, L.; Zhao, W.; Su, H.; Cheng, X. Higher transcription levels in ascorbic acid biosynthetic and recycling genes were associated with higher ascorbic acid accumulation in blueberry. Food Chem. 2015, 188, 399-405. [CrossRef] [PubMed]

90. Poulose, S.M.; Bielinski, D.F.; Carrihill-Knoll, K.L.; Rabin, B.M.; Shukitt-Hale, B. Protective effects of blueberry-and strawberry diets on neuronal stress following exposure to (56)Fe particles. Brain Res. 2014, 1593, 9-18. [CrossRef] [PubMed]

91. Oh, D.R.; Kim, Y.; Choi, E.J.; Jung, M.A.; Oh, K.N.; Hong, J.A.; Bae, D.; Kim, K.; Kang, H.; Kim, J.; et al. Antidepressant-like effects of Vaccinium bracteatum in chronic restraint stress mice: Functional actions and mechanism explorations. Am. J. Chin. Med. 2018, 46, 357-387. [CrossRef] [PubMed]

92. Tan, L.; Yang, H.P.; Pang, W.; Lu, H.; Hu, Y.D.; Li, J.; Lu, S.J.; Zhang, W.Q.; Jiang, Y.G. Cyanidin-3-O-galactoside and blueberry extracts supplementation improves spatial memory and regulates hippocampal ERK expression in senescence-accelerated mice. Biomed. Environ. Sci. 2014, 27, 186-196. [PubMed]

93. Jeong, H.R.; Jo, Y.N.; Jeong, J.H.; Kim, H.J.; Kim, M.J.; Heo, H.J. Blueberry (Vaccinium virgatum) leaf extracts protect against $\mathrm{A} \beta$-induced cytotoxicity and cognitive impairment. J. Med. Food 2013, 16, 968-976. [CrossRef] [PubMed]

94. Fragua, V.; Lepoudère, A.; Leray, V.; Baron, C.; Araujo, J.A.; Nguyen, P.; Milgram, N.W. Effects of dietary supplementation with a mixed blueberry and grape extract on working memory in aged beagle dogs. J. Nutr. Sci. 2017, 6, e35. [CrossRef] [PubMed]

95. Boespflug, E.L.; Eliassen, J.C.; Dudley, J.A.; Shidler, M.D.; Kalt, W.; Summer, S.S.; Stein, A.L.; Stover, A.N.; Krikorian, R. Enhanced neural activation with blueberry supplementation in mild cognitive impairment. Nutr. Neurosci. 2017, 21, 1-9. [CrossRef] [PubMed]

96. Ma, H.; Johnson, S.L.; Liu, W.; DaSilva, N.A.; Meschwitz, S.; Dain, J.A.; Seeram, N.P. Evaluation of polyphenol anthocyanin-enriched extracts of blackberry, black raspberry, blueberry, cranberry, red raspberry, and strawberry for free radical scavenging, reactive carbonyl species trapping, anti-glycation, anti- $\beta$-amyloid aggregation, and microglial neuroprotective effects. Int. J. Mol. Sci. 2018, 19, E461. [CrossRef] [PubMed]

97. Senevirathne, M.; Kim, S.H.; Jeon, Y.J. Protective effect of enzymatic hydrolysates from highbush blueberry (Vaccinium corymbosum L.) against hydrogen peroxide-induced oxidative damage in Chinese hamster lung fibroblast cell line. Nutr. Res. Pract. 2010, 4, 183-190. [CrossRef] [PubMed]

98. Zhang, J.; Lazarenko, O.P.; Blackburn, M.L.; Shankar, K.; Badger, T.M.; Ronis, M.J.J.; Chen, J.R. Feeding blueberry diets in early life prevent senescence of osteoblasts and bone loss in ovariectomized adult female rats. PLoS ONE 2011, 6, e24486. [CrossRef] [PubMed]

99. Devareddy, L.; Hooshmand, S.; Collins, J.K.; Lucas, E.A.; Chai, S.C.; Arjmandi, B.H. Blueberry prevents bone loss in ovariectomized rat model of postmenopausal osteoporosis. J. Nutr. Biochem. 2008, 19, 694-699. [CrossRef] [PubMed]

100. Nair, A.R.; Mariappan, N.; Stull, A.J.; Francis, J. Blueberry supplementation attenuates oxidative stress within monocytes and modulates immune cell levels in adults with metabolic syndrome: A randomized, double-blind, placebo-controlled trial. Food Funct. 2017, 8, 4118-4128. [CrossRef] [PubMed]

101. Wang, Y.P.; Cheng, M.L.; Zhang, B.F.; Mu, M.; Zhou, M.Y.; Wu, J.; Li, C.X. Effect of blueberry on hepatic and immunological functions in mice. Hepatobil. Pancreat. Dis. Int. 2010, 9, 164-168. 
102. Lu, S.; Cheng, M.L.; Li, H.; Wu, J. Study of potential protective effects of blueberry on hepatic cytochrome P450 2E1 expression in rats with immune hepatic fibrosis. Zhonghua Gan Zang Bing Za Zhi 2012, 20, 497-502. (In Chinese) [PubMed]

103. Lewis, E.D.; Ren, Z.; DeFuria, J.; Obin, M.S.; Meydani, S.N.; Wu, D. Dietary supplementation with blueberry partially restores T-cell-mediated function in high-fat-diet-induced obese mice. Br. J. Nutr. 2018, 119, 1393-1399. [CrossRef] [PubMed]

104. Ahrén, I.L.; Xu, J.; Önning, G.; Olsson, C.; Ahrné, S.; Molin, G. Antihypertensive activity of blueberries fermented by Lactobacillus plantarum DSM 15313 and effects on the gut microbiota in healthy rats. Clin. Nutr. 2015, 34, 719-726. [CrossRef] [PubMed]

105. McAnulty, L.S.; Collier, S.R.; Landram, M.J.; Whittaker, D.S.; Isaacs, S.E.; Klemka, J.M.; Cheek, S.L.; Arms, J.C.; McAnulty, S.R. Six weeks daily ingestion of whole blueberry powder increases natural killer cell counts and reduces arterial stiffness in sedentary males and females. Nutr. Res. 2014, 34, 577-584. [CrossRef] [PubMed]

106. Johnson, S.A.; Figueroa, A.; Navaei, N.; Wong, A.; Kalfon, R.; Ormsbee, L.T.; Feresin, R.G.; Elam, M.L.; Hooshmand, S.; Payton, M.E.; et al. Daily blueberry consumption improves blood pressure and arterial stiffness in postmenopausal women with pre- and stage 1-hypertension: A randomized, double-blind, placebo-controlled clinical trial. J. Acad. Nutr. Diet. 2015, 115, 369-377. [CrossRef] [PubMed]

107. Lasekan, O. Exotic berries as a functional food. Curr. Opin. Clin. Nutr. Metab. Care 2014, 17, 589-595. [CrossRef] [PubMed]

108. Whyte, A.R.; Cheng, N.; Fromentin, E.; Williams, C.M. A randomized, double-blinded, placebo-controlled study to compare the safety and efficacy of low dose enhanced wild blueberry powder and wild blueberry extract (ThinkBlue ${ }^{\mathrm{TM}}$ ) in maintenance of episodic and working memory in older adults. Nutrients 2018, 10, 660. [CrossRef] [PubMed]

109. Li, H.; Tan, L.; Yang, H.P.; Pang, W.; Xu, T.; Jiang, Y.G. Changes of hippocampus proteomic profiles after blueberry extracts supplementation in APP/PS1 transgenic mice. Nutr. Neurosci. 2018, 1-10. [CrossRef] [PubMed]

110. Zhang, C.Y.; Guo, Q.-G.; Liu, Y.J.; Liu, H.C.; Wang, F.G.; Jia, C.G. Molecular cloning and functional analysis of a flavanone 3-hydroxylase gene from blueberry. J. Hortic. Sci. Biotechnol. 2017, 92, 57-64. [CrossRef]

111. Baba, A.B.; Nivetha, R.; Chattopadhyay, I.; Nagini, S. Blueberry and malvidin inhibit cell cycle progression and induce mitochondrial-mediated apoptosis by abrogating the JAK/STAT-3 signalling pathway. Food Chem. Toxicol. 2017, 109, 534-543. [CrossRef] [PubMed]

112. McGill, C.M.; Brown, T.J.; Cheng, Y.Y.; Fisher, L.N.; Shanmugavelandy, S.S.; Gustafson, S.J.; Dunlap, K.L.; Lila, M.A.; Kester, M.; Toran, P.T.; et al. Therapeutic effect of blueberry extracts for acute myeloid leukemia. Int. J. Biopharm. Sci. 2018, 1, 102. [PubMed]

113. Adams, L.S.; Phung, S.; Yee, N.; Seeram, N.P.; Li, L.; Chen, S. Blueberry phytochemicals inhibit growth and metastatic potential of MDA-MB-231 breast cancer cells through modulation of the phosphatidylinositol 3-kinase pathway. Cancer Res. 2010, 70, 3594-3605. [CrossRef] [PubMed]

114. Chen, Q.; Li, S.; Jia, Y.; Wang, L. Blueberry anthocyanins induce G2/M cell cycle arrest and apoptosis of oral cancer KB cells through down-regulation methylation of p53. Yi Chuan 2014, 36, 566-573. (In Chinese)

115. Wu, T.; Gao, Y.; Guo, X.; Zhang, M.; Gong, L. Blackberry and blueberry anthocyanin supplementation counteract high-fat-diet-induced obesity by alleviating oxidative stress and inflammation and accelerating energy expenditure. Oxid. Med. Cell Longev. 2018, 2018, 4051232. [CrossRef] [PubMed]

116. Song, Y.; Park, H.J.; Kang, S.N.; Jang, S.H.; Lee, S.J.; Ko, Y.G.; Kim, G.S.; Cho, J.H. Blueberry peel extracts inhibit adipogenesis in 3T3-L1 cells and reduce high-fat diet-induced obesity. PLoS ONE 2013, 8, e69925. [CrossRef] [PubMed]

117. Li, X.; Sun, H.; Pei, J.; Dong, Y.; Wang, F.; Chen, H.; Sun, Y.; Wang, N.; Li, H.; Li, Y. De novo sequencing and comparative analysis of the blueberry transcriptome to discover putative genes related to antioxidants. Gene 2012, 511, 54-61. [CrossRef] [PubMed]

118. Huang, W.Y.; Wu, H.; Li, D.J.; Song, J.F.; Xiao, Y.D.; Liu, C.Q.; Zhou, J.Z.; Sui, Z.Q. Protective effects of blueberry anthocyanins against $\mathrm{H}_{2} \mathrm{O}_{2}$-induced oxidative injuries in human retinal pigment epithelial cells. J. Agric. Food Chem. 2018, 66, 1638-1648. [CrossRef] [PubMed] 
119. Huang, W.; Yan, Z.; Li, D.; Ma, Y.; Zhou, J.; Sui, Z. Antioxidant and anti-inflammatory effects of blueberry anthocyanins on high glucose-induced human retinal capillary endothelial cells. Oxid. Med. Cell Longev. 2018, 201, 1862462. [CrossRef] [PubMed]

120. Sun, J.; Wu, Y.; Long, C.; He, P.; Gu, J.; Yang, L.; Liang, Y.; Wang, Y. Anthocyanins isolated from blueberry ameliorates $\mathrm{CCl} 4$ induced liver fibrosis by modulation of oxidative stress, inflammation and stellate cell activation in mice. Food Chem. Toxicol. 2018, 120, 491-499. [CrossRef] [PubMed]

121. Zhu, J.J.; Cheng, M.L.; Zhou, M.Y.; Zhao, X.K. The effect of p-JAK1/p-STAT3 signaling way in intervening NAFLD by blueberry probiotic serum. J. Sichuan Univ. (Med. Sci. Ed.) 2017, 48, 203-209. (In Chinese)

122. Nair, A.R.; Elks, C.M.; Vila, J.; Del Piero, F.; Paulsen, D.B.; Francis, J. A blueberry-enriched diet improves renal function and reduces oxidative stress in metabolic syndrome animals: Potential mechanism of TLR4-MAPK signaling pathway. PLoS ONE 2014, 9, e111976. [CrossRef] [PubMed]

123. Koupý, D.; Kotolová, H.; Kučerová, J. Effectiveness of phytotherapy in supportive treatment of type 2 diabetes mellitus billberry (Vaccinium myrtillus). Ceska. Slov. Farm. 2015, 64, 3-6. [PubMed]

124. Milbury, P.E.; Kalt, W. Xenobiotic metabolism and berry flavonoid transport across the blood-brain barrier. J. Agric. Food Chem. 2010, 58, 3950-3956. [CrossRef] [PubMed]

125. Williams, C.M.; El Mohsen, M.A.; Vauzour, D.; Rendeiro, C.; Butler, L.T.; Ellis, J.A.; Whiteman, M.; Spencer, J.P. Blueberry-induced changes in spatial working memory correlate with changes in hippocampal CREB phosphorylation and brain-derived neurotrophic factor (BDNF) levels. Free Rad. Biol. Med. 2008, 45, $295-305$. [CrossRef] [PubMed]

126. Cásedas, G.; González-Burgos, E.; Smith, C.; López, V.; Gómez-Serranillos, M.P. Regulation of redox status in neuronal SH-SY5Y cells by blueberry (Vaccinium myrtillus L.) juice, cranberry (Vaccinium macrocarpon A.) juice and cyanidin. Food Chem. Toxicol. 2018, 118, 572-580. [CrossRef] [PubMed]

127. Yan, X.; Wu, L.; Li, B.; Meng, X.; Dai, H.; Zheng, Y.; Fu, J. Cyanidin-3-O-glucoside attenuates acute lung injury in sepsis rats. J. Surg. Res. 2015, 199, 592-600. [CrossRef] [PubMed]

128. Zeng, Y.; Li, Y.; Yang, J.; Pu, X.; Du, J.; Yang, X.; Yang, T.; Yang, S. Therapeutic role of functional components in alliums for preventive chronic disease in human being. Evid.-Based Complement. Altern. Med. 2017, 2017, 9402849. [CrossRef] [PubMed]

129. Zeng, Y.W.; Pu, X.Y.; Yang, J.Z.; Du, J.; Yang, X.; Li, X.; Li, L.; Zhou, Y.; Yang, T. Preventive and therapeutic role of functional ingredients of barley grass for chronic diseases in human beings. Oxid. Med. Cell. Longev. 2018, 2018, 3232080. [CrossRef] [PubMed]

130. Cocetta, G.; Rossoni, M.; Gardana, C.; Mignani, I.; Ferrante, A.; Spinardi, A. Methyl jasmonate affects phenolic metabolism and gene expression in blueberry (Vaccinium corymbosum). Physiol. Plant. 2015, 153, 269-283. [CrossRef] [PubMed]

131. Liu, Y.; Wang, D.; Zhang, D.; Lv, Y.; Wei, Y.; Wu, W.; Zhou, F.; Tang, M.; Mao, T.; Li, M.; et al. Inhibitory effect of blueberry polyphenolic compounds on oleic acid-induced hepatic steatosis in vitro. J. Agric. Food Chem. 2011, 59, 12254-12263. [CrossRef] [PubMed]

132. Huang, W.; Yao, L.; He, X.; Wang, L.; Li, M.; Yang, Y.; Wan, C. Hypoglycemic activity and constituents analysis of blueberry (Vaccinium corymbosum) fruit extracts. Diabetes Metab. Syndr. Obes. 2018, 11, 357-366. [CrossRef] [PubMed]

133. Johnson, M.H.; Lucius, A.; Meyer, T.; de Mejia, E.G. Cultivar evaluation and effect of fermentation on antioxidant capacity and in vitro inhibition of $\alpha$-amylase and $\alpha$-glucosidase by highbush blueberry (Vaccinium corombosum). J. Agric. Food Chem. 2011, 59, 8923-8930. [CrossRef] [PubMed]

134. Cuevas, A.; Saavedra, N.; Salazar, L.A.; Abdalla, D.S. Modulation of immune function by polyphenols: Possible contribution of epigenetic factors. Nutrients 2013, 5, 2314-2332. [CrossRef] [PubMed]

135. Uysal, U.; Seremet, S.; Lamping, J.W.; Adams, J.M.; Liu, D.Y.; Swerdlow, R.H.; Aires, D.J. Consumption of polyphenol plants may slow aging and associated diseases. Curr. Pharm. Des. 2013, 19, 6094-6111. [CrossRef] [PubMed]

136. Nair, A.R.; Masson, G.S.; Ebenezer, P.J.; Del Piero, F.; Francis, J. Role of TLR4 in lipopolysaccharide -induced acute kidney injury: Protection by blueberry. Free Rad. Biol. Med. 2014, 71, 16-25. [CrossRef] [PubMed]

137. Bensalem, J.; Dudonné, S.; Gaudout, D.; Servant, L.; Calon, F.; Desjardins, Y.; Layé, S.; Lafenetre, P.; Pallet, V. Polyphenol-rich extract from grape and blueberry attenuates cognitive decline and improves neuronal function in aged mice. J. Nutr. Sci. 2018, 7, e19. [CrossRef] [PubMed] 
138. Maulik, M.; Mitra, S.; Hunter, S.; Hunstiger, M.; Oliver, S.R.; Bult-Ito, A.; Taylor, B.E. Sir-2.1 mediated attenuation of $\alpha$-synuclein expression by Alaskan bog blueberry polyphenols in a transgenic model of Caenorhabditis elegans. Sci. Rep. 2018, 8, 10216. [CrossRef] [PubMed]

139. Hong, S.M.; Soe, K.H.; Lee, T.H.; Kim, I.S.; Lee, Y.M.; Lim, B.O. Cognitive improving effects by highbush blueberry (Vaccinium crymbosum L.) vinegar on scopolamine-induced amnesia mice model. J. Agric. Food Chem. 2017, 66, 99-107. [CrossRef] [PubMed]

2018 by the authors. Licensee MDPI, Basel, Switzerland. This article is an open access article distributed under the terms and conditions of the Creative Commons Attribution (CC BY) license (http://creativecommons.org/licenses/by/4.0/). 